\title{
The influence of school leadership preparation programmes: Identification of possible focus areas
}

\author{
G. M. Steyn \\ Department of Further Teacher Education \\ University of South Africa \\ South Africa \\ e-mail: steyngm1@unisa.ac.za
}

\begin{abstract}
The Higher Education Quality Committee (HEQC) is responsible for the accreditation of public and private institutions and their learning programmes in South Africa. This body has identified a number of criteria in order to determine the effectiveness of school leadership preparation programmes. One of them focuses on the influence of the programme on school practice. The article attempts to identify possible areas of investigation in order to evaluate the influence of preparation programmes for school managers. Three major focus areas are identified that can be used to in assessing the influence of preparation programmes for school managers: setting a course, developing people and developing the organisation.
\end{abstract}

\section{INTRODUCTION}

There have been numerous and impassioned calls for positive change in education provision. Calls for school improvement, greater accountability, shared governance, parental choice and school safety have escalated within and outside schools (Levine 2005, 5; Southworth and Du Quesnay 2005, 219; Wilmore 2000, 349). Most critiques of the current state of affairs seem to regard improved leadership and management as a way to provide better quality education (Slater, McGhee, Capt, Alvarez, Topete and Iturbe 2003, 39).

In the current climate where the emphasis is on student performance, school leaders are held accountable for the quality of teaching and for how much learners learn (Leithwood and Riehl 2003, 1). This implies that school leaders have to be prepared effectively to create good schools 'so that the human energy in schools is transformed into desired student academic and social growth' (Grogan and Andrews 2002, 234). They also have to serve all students well and react to the increasingly complex environments of the 21st century (Fusarelli and Smith 1999, 535; Hale and Moorman 2003, 5; Johnson and Uline 2005, 51; Leithwood and Riel 2003, 1). This also explains why preparation for school leadership and management was one of the major issues of the late 1990s (Bush 1998, 321). 
As is the case in other countries, principals in South Africa are faced with a huge task as they attempt to create an effective learning environment in schools (Mestry and Grobler 2004, 2). The numerous demands and challenges include establishing a culture of teaching and learning, maintaining high educational standards and improving performance where necessary, working collaboratively with parents, dealing with multicultural school populations, managing change and conflict; coping with limited resources, and ensuring greater accountability to their respective communities (Mestry and Grobler 2004, 3; Vick 2004, 10). Factors outside schools may infringe on their jurisdiction, for example teacher unions and the Department of Education may negotiate matters such as workload, staff discipline, grievances and class size. Principals must have the necessary skills to cope with changes. New types of leadership are required to address such changes and preparation programmes for principals should accommodate this need.

In accordance with the Higher Education Act 101 of 1997 the Higher Education Quality Committee (HEQC) is responsible for the accreditation of public and private institutions and their learning programmes in South Africa (Council for Higher Education 2005, 5). The underlying objective of the HEQC with regard to quality assurance is to ensure high quality and the effective and efficient delivery of education, training and community service in institutions which develop appropriate knowledge and skills for graduates for the sake of social and economic progress (Council for Higher Education 2001, 2). The HEQC has identified a number of criteria in order to determine the effectiveness of programmes. One of them focuses on the influence of the programme. Institutions are required to provide evidence that studies are undertaken to measure and evaluate the influence of the programme and its graduates (Council for Higher Education 2005, 11).

This article attempts to identify possible areas of investigation in order to establish the influence of preparation programmes for school managers. A review of literature on school leadership was undertaken using Internet searches and the library to identify such areas. To establish the influence of programmes, it is necessary first to understand the influence of school leadership in the functioning of schools.

\section{THE INFLUENCE OF SCHOOL LEADERSHIP}

Numerous studies confirm the importance of leadership in the functioning of organisations (Amey 2005, 701; Hallinger 2005, 1). Hale and Moorman (2003, 5) state that effective leadership is at the heart of all successful organisations. As regards the influence of school leadership, the literature survey reveals the following:

- It is agreed that school leaders have an influence on the running of schools and that they play a key role in school improvement (Hess and Kelly 2005, 2; Lin 2005, 21; Southworth and Du Quesnay 2005, 219).

- Leithwood and Riehl $(2003,40)$ are of the opinion that school leadership has a significant influence on student learning which is second only to the influence 
of teachers' teaching and the quality of the curriculum. Although large-scale quantitative studies of schooling indicate that the influence of school leadership on student performance is small, they conclude that it is, nevertheless, significant.

- The key role of educational leaders in creating schools where a diverse student body attains academic success has been emphasised in research for more than 25 years (Johnson and Uline 2005, 45; Hallinger 2005, 1; Vick 2004, 34). Effective principals are even regarded as the 'catalysts' for effective schools (Lin 2005, iii).

- School leadership has benefits for the individual teacher and the school (Harris 2004, 15). School leaders share power, involve others in decision-making and empower others to reflect on their own teaching practice (McKerrow, Dunn and Killian 2003,2). As such their leadership may have an influence on relationships, expectations and outcomes (Berry 2004, 1).

- Numerous studies on school effectiveness conclusively indicate that leadership quality is a key factor in determining the success or failure of schools (Bush 1998, 331; Hess and Kelly 2005, 2; Johnson and Uline 2005, 45; Vick 2004, 34).

Southworth and Du Quesnay $(2005,220)$ are more hesitant in their support of the above positive findings. According to them, seeking to prove that leadership makes a measurable and real difference remains a major challenge for principals and researchers. They also argue that, although there seems to be a vague conception of the causal factors that link leadership to student performance, these relationships vary and take time to determine.

Training programmes on school leadership have been criticised for equipping principals with skills to run schools as they exist today rather than forming leaders who can guide and develop schools for the future (Hallinger and Bridges in Wong 2004, 140; Levine 2005, 66 ). However, there is an ongoing need for a different type of school leader and different types of leadership preparation to address the changing contexts of education (Wong 2004, 143). This leads to the question whether leadership preparation can have an influence on school practice.

\section{DOES SCHOOL LEADERSHIP PREPARATION MAKE A DIFFERENCE?}

Researchers generally agree that programmes are needed to prepare school leaders if learners are to attain higher levels of performance (Grogan and Andrews 2002, 249; Hammersley-Fletcher and Brudrett 2005, 64; Lease 2002, 41). However, a literature review indicates various perspectives on the influence of leadership programmes on school practice and student performance. Studies in educational management, for example, cannot confirm that programmes have any influence on student performance in schools where graduates have been placed (Brundett (s.a.), 6; Levine 2005, 44). According to Levine $(2005,23)$ the curricula of programmes do not address the real needs of educational leaders. There is also a lack of research on the value of educational management programmes, the aspects in the programme that make a 
difference and what aspects are not needed or are minimally meaningful to enhance the growth and performance of learners in the school (Levine 2005, 44).

Lashway $(2003,1)$ is more explicit in his opinion that preparation programmes for principals generally are not highly effective. This position is further substantiated by a study of university-based programmes that indicates that the programmes reviewed are not sufficiently pragmatic and action-oriented to develop the necessary skills (Grogan and Andrews 2002, 246). According to Lashway (2003, 2), the relatively few studies on the influence of preparation programmes for principals do not conclusively support their overall effectiveness. Moreover, Murphy and Vriesenga in Levine $(2005,45)$ found that only three percent of studies on preparation programmes for educational leadership were empirical studies. What is of greater concern is that in an assessment of schools of education carried out in the USA students said that they did not view educational leadership studies as being very helpful: 89 per cent said that such studies do not prepare students to cope with classroom and school realities, while 55 per cent said that they are out of step with the times (Levine 2005, 44).

This is in contrast to the view of Daresh, Gantner, Dunlap and Hvizdak (2000, 72), who state that some preparation programmes for school leaders have succeeded in addressing the changing environment of schooling through the use of simulations, case studies and other means to reflect the conditions principals face in the 'real world'.

Menter, Holligan and Mthenjwa (2005) support the view of Daresh et al. (2000). Their national survey on the influence of the Scottish Qualification for Headship, which is a joint venture between higher education institutions and the Department of Education, provides a very positive picture of the influence of preparation programmes. In their study the following statements attracted the strongest support (Menter et al. 2005, 11): The programme enhanced my ability to support others; The programme increased my effectiveness as a leader; The programme extended my professional practice; The programme has made me a more reflective practitioner; and The programme was effective in developing my professional values. The responses also indicated a strong sense of individual professional development. The graduates were of the opinion that the programme assisted them to implement change and improve team work in their work environment. However, they were not so confident of their influence on the performance of students. Principals of schools where students were working were also asked to respond to evaluative statements on the influence of the programme on their school (Menter et al. 2005, 12). Although there is little evidence that the programme improved student performance, numerous professional evaluations have indicated that the programme has had an effect on the quality of teaching and learning at schools (Menter et al. 2005, 13). This is in line with the view of Grogan and Andrews $(2002,244)$, who believe that preparation programmes can lead to positive changes in schools, though studies indicate that little change has actually occurred.

The study of Menter et al. $(2005,18)$ also produced positive findings, but the authors acknowledge that determining the influence of a preparation programme in 
school leadership is difficult, if not impossible since there are so many other factors that may influence the quality of schools. This is very similar to the opinion expressed by Brundett ([s.a.], 6) who says that the effectiveness of leadership programmes in preparing and supporting school leaders for complex roles remains a 'developing' issue rather than one that has been 'confirmed'. What is very disturbing it that many students enrolled for preparation programmes are more attracted to the possibility of improved salary than to rigorous academic studies (Levine 2005, 31). They are more interested in 'ease of access and ease of program. They don't want to have to do too much work' (Levine 2005, 31).

From a different perspective, Grogan and Andrews (2002, 244, 245) state that it is unfair to blame preparation programmes for the state of schools: 'Even the most dedicated, enlightened reformer in the field is facing an uphill battle at present to bring about significant change'. This partially supports the view of Reeves, Turner, Morris and Forde $(1998,1850)$, who say that there is no guarantee that leadership qualifications will be the answer to making schools more effective. However, the belief that school leadership does make a difference to the functioning of schools is primarily the focus of leadership preparation programmes (Hallinger 2005, 1). There is also agreement that the effectiveness of principals depends on their appropriate training (Bush 1998, 331; Hess and Kelly 2005, 3). Although there is concern that preparation programmes do not prepare principals adequately, it remains a challenge for programme developers to prepare future leaders to assume effective leadership roles and to address the continuous changes in education (Amey 2005, 701; Daresh et al. 2000, 72; Wong 2004, 140).

\section{RECENT DEVELOPMENTS IN SCHOOL LEADERSHIP PREPARATION PROGRAMMES}

The approaches to principals' preparation programmes have been a general concern for some time, which explains the need for preparation programmes in leadership to change (Daresh et al. 2000, 69; Wong 2004, 143). There is agreement that previous programmes with their emphasis on management did not address current educational challenges and have not succeeded in guiding schools and assisting them to achieve academic success in the 21st century (Glatter 2006, 70; Hale and Moorman 2003, 10; Herrington and Wills 2005, 197; Levine 2005, 68; Wilmore 2000, 359).

Criticism of traditional and theory-based programmes, public demand for improved quality of leadership in schools and the new emphasis on the principal as 'leader of student learning' have paved the way for reconceptualisation and restructuring of preparation programmes and school practice (Fusarelli and Smith 1999, 535; Hale and Moorman 2003, 19; Lauder 2000, 23; Levine 2005, 68; Southworth and Du Quesnay 2005, 218; Vick 2004, 11; Wong 2004, 140). As a result of this, the focus of many programmes has changed from management to leadership preparation (Azzam 2005, 89 ; Glatter 2006, 70). However, Glatter $(2006,72,79)$ suggests a re-orientation of the field in order to associate management and leadership with organisation. Adopting 
the notion of 'organisation' as the core concept removes the dichotomy between the concepts of management and leadership that has otherwise been suggested (Glatter 2006, 72, 79; Amey 2005, 701). For Glatter $(2006,79)$ such a shift would provide a more holistic and systemic approach that could better inform practice. Glatter's re-orientation $(2006,74)$ towards systems organisation and thinking also strongly emphasises problem-solving, which requires reflection and certain cognitive skills.

Crow $(2003,2)$ and Herrington and Wills $(2005,198)$ also support the adoption of an organisational perspective on preparation programmes. Crow $(2003,2)$ links preparation programmes in educational leadership to two forms of socialisation, namely the learning of a new professional role (preparing for a new occupational role such as principal) and a new organisational role (focusing on the context in which the role is performed). Crow's view also coincides with that of McClay and Brown $(2003,85)$ and Mestry and Grobler $(2004,3)$, who believe that the individual's management development is best placed within the school context and should become a fundamental part of the daily management of schools. According to Mestry and Grobler (2004, 3), education management development should therefore be seen as a process whereby individual development and the achievement of organisational goals should be synchronised. This view is also in line with the findings of Southworth and Du Quesnay $(2005,218)$ and Amey $(2005,701)$, who see the role of leadership as one of the most important aspects of organisational functioning and learning. Amey $(2005,701)$ regards it as a challenge for programme developers to prepare future leaders to assume this kind of leadership role. Unfortunately many preparation programmes have been relatively slow in adapting this approach to principalship to face the challenges of 21 st century schooling (Fusarelli and Smith 1999, 535; Grogan and Andrews 2002, 240; Hale and Moorman 2003, 13; Hess and Kelly 2005, 38).

Table 1: Programme domains (Lauder 2000, 26)

\begin{tabular}{|c|c|}
\hline $\begin{array}{l}\text { Functional domain } \\
\text { Leadership } \\
\text { Information collection } \\
\text { Problem analysis } \\
\text { Judgement } \\
\text { Organisational oversight } \\
\text { Implementation } \\
\text { Delegation }\end{array}$ & $\begin{array}{l}\text { Programmatic domain } \\
\text { Instruction and the learning environment } \\
\text { Curriculum design } \\
\text { Student guidance and development } \\
\text { Staff development } \\
\text { Measurement and evaluation } \\
\text { Resource allocation }\end{array}$ \\
\hline $\begin{array}{l}\text { Interpersonal domain } \\
\text { Motivating others } \\
\text { Interpersonal sensitivity } \\
\text { Oral and nonverbal expression } \\
\text { Written expression }\end{array}$ & $\begin{array}{l}\text { Contextual domain } \\
\text { Philosophical and cultural values } \\
\text { Legal and regulatory applications } \\
\text { Policy and political influence } \\
\text { Public relations }\end{array}$ \\
\hline
\end{tabular}


From a review of the literature it seems as if most programmes currently focus on four domains: the functional domain, the programmatic domain, the interpersonal domain and the contextual domain (Lauder 2000, 25) as reflected in Table 1. These domains also overlap the areas for effective leadership preparation identified by Hess and Kelly $(2005,5,6)$ : managing for results; technical knowledge; external leadership; norms and values managing classroom instruction; and leadership and school culture. They also coincide with the skills required by education leaders as outlined by Lease $(2002,41)$ : human relations, planning, understanding technology, diversity, multicultural and gender issues and school law.

To sustain programme effectiveness, it is important to evaluate such programmes continuously (Lauder 2000, 27). Evaluation of programmes is also an important component in preparation programmes (Wong 2004, 143). The idea of programme evaluation dates back to the work of Tyler (1949 in Wong 2004), who viewed evaluation as an essential element of the education process. Such evaluations can help to address the emerging changes in the work of principals (Gonzales, Glasman and Glasman 2002,280). Programme evaluation can change training into a 'powerful force' that has value for both school and society (Spitzer in Wong 2004, 144). It means critically reviewing the influence that the programme has had as evidenced by the way in which graduates and institutions have benefited from leadership development (Lauder 2000, 27; Wong 2004, 143).

In order to determine the possible influence of preparation programmes, it is necessary to focus on the prerequisites of school leadership in schools.

\section{PREREQUISITES FOR EFFECTIVE EDUCATIONAL LEADERS}

Education management has changed considerably since it first evolved as a formal role in the 1920s (Brundrett 2000,354; Grogan and Andrews 2002, 234). The concept underwent many modifications before the role of the principal emerged as that of an instructional leader during the late 1980s and 1990s (Daresh et al. 2000, 71; Grogan and Andrews 2002, 239; Hale and Moorman 2003, 10; Lin 2005, 21). The education manager's role is now seen to focus on stability, manageability and to some extent on accomplishments while the education leader's role focuses on action, joint decisionmaking and emphasis on the future (Daresh et al. 2000, 69; Hammersley-Fletcher and Brudrett 2005, 61; Vick 2004, 13).

Although current perspectives on educational leadership differ, there is a movement away from perspectives that view principals as managers towards perspectives that view principals as instructional leaders who focus on teaching and learning in schools (Grogan and Andrews 2002, 244; Johnson and Uline 2005, 48; Lin 2005, 21; Reeves et al. 1998, 192; Quinn 2002, 18; Southworth and Du Quesnay 2005, 218; Vick 2004, 33). The greatest change in the running of schools has been the move to site-based management, that is, towards the idea of participative, collaborative forms of school leadership and management (Grogan and Andrews 2002, 240; Johnson and Uline $2005,48)$. Once leadership becomes collaborative and devolved, leaders play a key 
role in maintaining and developing the relationships between people, influencing the way interaction occurs and also the way individuals are developed (HammersleyFletcher and Brudrett 2005, 61). In site-based management flatter, team-based structures develop and different kinds of leadership evolve as a consequence of such development (Leithwood and Riehl 2003, 4).

Principals have to possess certain leadership abilities to achieve and maintain quality schools in complex environments (Daresh et al. 2000, 69; Fennell 2005, 145; Hale and Moorman 2003, 13; Vick 2004, 11). Such complex environments also imply that school leaders should be equipped with 'multifaceted skills' (Vick 2004, 11) which form the prerequisites for successful leadership (Leithwood and Riehl 2003, 5-7). They include the prerequisites given in Table 2 .

Table 2: Prerequisites of effective educational leaders

\begin{tabular}{|c|c|}
\hline \multicolumn{2}{|c|}{1 SETTING DIRECTION } \\
\hline $\begin{array}{l}1.1 \text { Creating and } \\
\text { sharing a focussed } \\
\text { vision and mission } \\
\text { to improve student } \\
\text { performance }\end{array}$ & $\begin{array}{l}\text { - Aligning vision and mission, priorities and values to context } \\
\text { of the school } \\
\text { - Endowed with charismatic leadership }\end{array}$ \\
\hline $\begin{array}{l}1.2 \text { Cultivating } \\
\text { the acceptance of } \\
\text { cooperative goals }\end{array}$ & $\begin{array}{l}\text { - Developing and valuing collaboration and caring about } \\
\text { each other } \\
\text { - Valuing people required to build trust and support }\end{array}$ \\
\hline $\begin{array}{l}\text { 1.3 Creating high } \\
\text { performance } \\
\text { expectations }\end{array}$ & $\begin{array}{l}\text { - Creating high performance expectations of staff to improve } \\
\text { student performance } \\
\text { - Informing staff about performance expectations } \\
\text { - Working effectively with adults }\end{array}$ \\
\hline \multicolumn{2}{|c|}{2 DEVELOPING PEOPLE } \\
\hline $\begin{array}{l}2.1 \text { Sharing } \\
\text { leadership } \\
\text { among members } \\
\text { in professional } \\
\text { communities }\end{array}$ & $\begin{array}{l}\text { - Willingness and know-how to share leadership } \\
\text { - Distributing instructional leadership } \\
\text { - Empowering staff } \\
\text { - Providing opportunities for staff to innovate, develop and } \\
\text { learn together }\end{array}$ \\
\hline $\begin{array}{l}2.2 \text { Providing an } \\
\text { appropriate model }\end{array}$ & $\begin{array}{l}\text { - Modelling, teaching and helping others to become better } \\
\text { followers } \\
\text { - Setting appropriate examples consistent with school leaders' } \\
\text { values } \\
\text { - Managing time effectively to meet school goals } \\
\text { - Being a transformational leader } \\
\text { - Cultivating higher levels of commitment to organisational } \\
\text { goals }\end{array}$ \\
\hline
\end{tabular}




\begin{tabular}{|c|c|}
\hline $\begin{array}{l}2.3 \text { Cultivating } \\
\text { learning among } \\
\text { all members in } \\
\text { the professional } \\
\text { community }\end{array}$ & $\begin{array}{l}\text { - Facilitating learning among all staff members } \\
\text { - Implementing good teaching practices } \\
\text { - Facilitating change to cultivate effective learning } \\
\text { - Invironment } \\
\text { - Merformance } \\
\text { - Monitoring of student performance } \\
\text { - Behaving in ways consistent with leaders' personal values, } \\
\text { - attitudes and beliefs } \\
\text { Promoting ethical practice }\end{array}$ \\
\hline $\begin{array}{l}\text { 2.4 Providing } \\
\text { individualised support }\end{array}$ & $\begin{array}{l}\text { - Acquiring and using resources intelligently to support and } \\
\text { monitor high levels of staff performance and needs } \\
\text { - Demonstrating respect for and concern about people's } \\
\text { personal feelings and needs } \\
\text { - Providing emotional, psychological and logistical support }\end{array}$ \\
\hline \multicolumn{2}{|c|}{3 DEVELOPING THE ORGANISATION } \\
\hline $\begin{array}{l}\text { 3.1 Developing } \\
\text { technical skills }\end{array}$ & $\begin{array}{l}\text { - Implementing site-based management } \\
\text { - Working with teams } \\
\text { - Planning strategically for the future } \\
\text { - Applying educational law to specific conditions } \\
\text { - Maintaining effective discipline }\end{array}$ \\
\hline $\begin{array}{l}\text { 3.2 Emphasising } \\
\text { learner-centred } \\
\text { leadership }\end{array}$ & $\begin{array}{l}\text { - Focussing on learner-centred leadership } \\
\text { - Employing instructional leadership }\end{array}$ \\
\hline $\begin{array}{l}\text { 3.3 Strengthening the } \\
\text { school culture }\end{array}$ & $\begin{array}{l}\text { - Creating and maintaining a safe learning environment } \\
\text { - Promoting ethical practices } \\
\text { - Resolving conflict }\end{array}$ \\
\hline $\begin{array}{l}\text { 3.4 Monitoring } \\
\text { organisational } \\
\text { performance }\end{array}$ & $\begin{array}{l}\text { - Using indicators to determine the school's effectiveness } \\
\text { - Monitoring both staff and learner performance }\end{array}$ \\
\hline
\end{tabular}

The three categories and their subcategories that are important and valuable for leadership practices in most educational contexts include the following: setting a course, developing people and developing the organisation.

\section{Setting a course}

In setting a course, school leaders attempt to develop school goals and encourage others with a vision of the future (Leithwood and Riehl 2003, 5). This involves the following interventions:

- Creating and sharing a focused vision and mission to improve student performance (Hess and Kelly 2005, 5; Kent 2002, 214; Vick 2004, 20). A new generation of school leaders are required to build a shared vision and work collaboratively 
to create good schools for all learners (Grogan and Andrews 2002, 251). The first characteristic of effective school leaders is their ability to align vision and mission, priorities and personal, professional and organisational values to the particular context in the school (Jabal 2006, 26; Leithwood and Riehl 2003, 5; Mester, Visser, Roodt and Kellerman 2002,73). Charisma may be critical in this respect. Charisma is a characteristic that describes leaders who are able to exert a profound influence on their followers, and the school's performance and climate by the power of their personality, personal charm, magnetism, inspiration, competence and emotion (Dreher 2002, 207).

- Cultivating the acceptance of cooperative goals. School leaders work mainly with and through other people (Leithwood and Riehl 2003,3). The acceptance of cooperative goals requires the cultivation of shared values and the development of an appreciation for the value of working together and caring about each other (Bernauer 2002, 90; Fennell 2005, 154; Hess and Kelly 2005, 5; Levine 2005, 54; Robinson and Carrington 2002, 241; Vick 2004, 26). Furthermore, valuing people is necessary to build trust and support in schools (Fennell 2005, 154; Hammersley-Fletcher and Brudrett 2005, 63).

- Creating high performance expectations. These are leaders' expectations for excellence, quality and high performance that may have an influence on relationships and outcomes in schools (Berry 2004, 1; Leithwood and Riehl 2003, 6). Through nurturing and caring relationships in schools, it is believed that student performance and social growth will be enhanced (Grogan and Andrews $2002,243)$. School leaders also have to keep everybody informed and focused on student performance (Hess and Kelly 2005, 5; Vick 2004, 21).

Leithwood and Riehl $(2003,3)$ believe that leaders create a shared sense of purpose and direction by working through other people. Studies consistently emphasise the influence of sound collegial relationships on change and school improvement (Harris 2002, 7).

\section{Developing people}

Teaching is often viewed as a lonely profession (Mitchell and Sackney in Fennell $2005,146)$. This isolation can be reduced by developing a professional community at schools (Fennell 2005, 146), which will involve the leader in activities such as the following:

- Sharing leadership among members of professional communities. Principals are key players at schools since they have to manage through collaborative and educational thinking about leadership that emphasises their role as leaders of an instructional team (Grogan and Andrews 2002, 243; Johnson and Uline 2005, 48; Lin 2005, 21; Quinn 2002, 18; Vick 2004, 33). Leadership in professional communities therefore involves shared leadership, in particularwhere instructional 
leadership is distributed and expanded throughout the school, thus increasing delegated powers (Fennell 2005, 156; Leithwood and Riehl 2003, 5; Quinn 2002, 17; Southworth and Du Quesnay 2005, 218). Instructional leadership, however, implies that the incumbent has expert knowledge and uses this knowledge to improve student performance (McKerrow et al. 2003, 3). Sharing leadership and knowledge can be a tool for staff members' empowerment and can be linked to feeling valued (Grogan and Andrews 2002, 240; Hammersley-Fletcher and Brudrett 2005, 62; McKerrow et al. 2003, 5). Empowering staff is based on the idea that 'if schools are to become better at providing learning for students then they must also become better at providing opportunities for teachers to innovate, develop and learn together' (Harris 2002, 9). In an empowering environment leaders also encourage staff to solve problems (Amey 2005, 692). Teacher empowerment does not remove the autonomy of principals, but should rather create a new and healthy form of shared leadership. This, however, implies a willingness by leaders to share the fruits of their leadership and knowledge with staff (Levine $2005,54)$. Through this approach the science of management has been replaced by the psychology of leadership, which emphasises interpersonal relationships and focuses on follower development and enhancement of student performance (Grogan and Andrews 2002, 243; Lease 2002, 41; Reeves et al. 1998, 192).

Devolving power to the school level does not necessarily increase the possibility of teacher empowerment if authority and control remain firmly in the hands of the school management team. Therefore, the ability and willingness to share power as well as the leadership style of school managers will strongly influence staff empowerment. School managers who are power hungry or who have autocratic leadership styles may feel threatened - a condition which is not reconcilable with empowerment. Empowerment needs leaders who are confident, have a strong sense of direction and who are willing to become a facilitator and an equal in decision-making processes. The change in leadership, leadership style and member expectations depend on the clarity of goals, the establishment of trust and effective communication patterns and members being able to regard themselves as potential leaders (Amey 2005, 699; Johnson and Uline 2005, 48; Hammersley-Fletcher and Brudrett 2005, 62).

- Cultivating learning among all members in the professional community. Facilitating learning for the individual leader as well as the members of the professional community is viewed as the primary goal of leadership (Amey 2005, 690). When leadership is viewed as learning, the creation of a learning environment becomes a primary organisational priority that is expressed along a developmental continuum (Amey 2005, 692; Hammersley-Fletcher and Brudrett 2005, 63; Vick 2004, 27). Employing a learning approach to leadership means that facilitation of learning among staff members has become an important role of leaders (Amey 2005, 701; Hammersley-Fletcher and Brudrett 2005, 74; Southworth and Du Quesnay 2005, 218; Vick 2004, 10). Such school leaders also respect life-long learning and 
recognise and encourage the implementation of good instructional practices that improve student performance (Daresh et al. 2000, 76; Vick 2004, 21). In this way staff members develop as professionals and assume more collective responsibility for joint decision-making and collective responsibility (Amey 2005, 701). Furthermore, appropriate structures or relationships have to be built at schools so that the ensuing human energy may improve learner achievement (Wilmore 2000, 349; Hale and Moorman 2003, 9).

- All members learn together in professional communities since they are collaborative communities (Fennell 2005, 147; Harris 2004, 23). In learning organisations leaders play a key role by having a clear vision for the organisation regarding how the staff can attain common goals. They do not impose goals on staff, but work collaboratively to create a sense of purpose and direction (Leithwood and Riel 2003, 3). Schools as communities are also characterised by professional learning as a way of achieving quality education (Fennell 2005, 146).

- Providing an appropriate model. The school leader's role is 'grounded in shared ideals where the leader serves as the head follower by modelling, teaching, and helping others to become better followers' (McKerrow et al. 2003, 2). Examples are also set for staff to follow which are consistent with the values their leaders advocate (Yu, Leithwood and Jantzi 2000, 371; Leithwood and Riehl 2003, 6). It implies that leadership should become transformational in nature (Grogan and Andrews 2002, 241; McKerrow et al. 2003, 5). Transformational forms of leadership fundamentally aim to make events meaningful and to cultivate higher levels of commitment to organisational goals on the part of staff (Bernauer 2002, 90; Yu et al. 2000, 370).

- Providing individualised support. School leaders acquire and use resources intelligently to support and monitor high levels of student and staff performance (Leithwood and Riehl 2003, 6; Vick 2004, 21). Support of this kind refers to demonstrating respect and concern for individuals' personal feelings and needs (Yu et al. 2000, 370). It is also important to provide emotional, psychological and logistical support to educators to enable them to continue developing new habits so that new procedures can become routine (Anonymous 2001/2002, 18; Somers and Sikorova 2002, 103; Sparks 2003, 43).

As mentioned before, leaders play a key role by having a clear vision for the organisation of how to attain common organisational goals (Fennell 2005, 147; Hess and Kelly 2005, 5; Levine 2005, 54).

\section{Developing the organisation}

Education leaders create a school environment, mobilise teachers and direct efforts for the sake of student learning (Jabal 2006, 26; Vick 2004, 27). This depends on 
their ability to lead their team of educators and to create an ethos that generates committed educators and inspired learners in an effective school setting (Parker and Day 1997, 87; Terry 1999, 28). This will require leaders to focus on activities such as the following:

- Developing technical skills. These leadership skills refer to the skills required to implement site-based management, work with teams, plan strategically for the future and maintain effective discipline (Daresh et al. 2000, 76).

- Emphasisinglearner-centredleadership. 'Learner-centredleadershipisconcerned with influencing the quality of teaching and student outcomes' (Southworth and Du Quesnay 2005, 218). It creates a school organisation where staff understand that every student counts and where every student has the support of a caring adult (Hess and Kelly 2005, 5; Vick 2004, 21). Furthermore, education leaders must believe that all students can succeed (Johnson and Uline 2005, 47). This implies that they should create school environments in which students are respected and valued (Vick 2004, 27). Instructional leadership is the key: principals should operate as lynchpins facilitating change and creating an effective learning environment in schools (Hammersley-Fletcher and Brudrett 2005, 63; Hale and Moorman 2003, 10; McClay and Brown 2003, 84; Southworth and Du Quesnay 2005, 218; Vick 2004, 34).

- Strengthening the school culture. Education leaders create and maintain safe and effective school environments for the sake of student performance (HammersleyFletcher and Brudrett 2005, 61; Hale and Moorman 2003, 5; Vick 2004, 32). Their leadership is overwhelmingly important in establishing a positive school culture (Hess and Kelly 2005, 5; Leithwood and Riehl 2003, 7). Without effective leadership, in particular transformational leadership, efforts to change the school culture and influence educator commitment and student performance are likely to fail (Bernauer 2002, 90; Vick 2004, 34). Such an environment should also make staff feel valued and respected (Johnson and Uline 2005, 47). Furthermore, ethical practices in schools should be promoted and conflicts should be managed effectively (Daresh et al. 2000, 76).

- Monitoring organisational performance. Unlike in the past when principals believed that educators needed constant control, the current leadership approach is to ensure that agreed-upon organisational goals and outputs are achieved by entrusting educators and learners to work towards these without constant supervision (Parker and Day 1997, 87). It is, however, necessary for school leaders to determine the school's effectiveness by using multiple indicators to continuously monitor learner progress and teacher effectiveness (Grogan and Andrews 2002, 239; Johnson and Uline 2005, 47; Leithwood and Riehl 2003, 6). It means that they should be equipped with the necessary skills to collect and analyse data in order to monitor both staff and learner performance. 


\section{CONCLUSION}

A new generation of school leaders is required to create effective schools. Preparation programmes at research universities can play a vital role in equipping principals with the necessary skills and competencies to positively influence student performance. As such the core objective of all these professional programmes should be to promote high quality learning among all students at schools (Kent 2002, 230). Daresh et al. $(2000,81)$ are of the opinion that the manner in which people study leadership will directly influence what they do as school leaders.

The question we need to answer is: how should the influence of preparation programmes be assessed? In essence, preparation programmes should at first address the individual professional development of principals and ultimately lead to effective learning by learners. The latter in itself is very complex and depends on other influential factors. Nevertheless, this article attempts to identify three major focus areas in assessing the influence of preparation programmes: setting a course, developing people and developing the organisation. These areas can be used to judge the influence of preparation programmes for school managers. 'The longevity of leadership development rests, in large part, on being able to describe the differences leaders make in terms of improvements to school and students' performance' (Southworth and Du Quesnay 2005, 220).

\section{REFERENCES}

Amey, M. J. 2005. Leadership as learning: Conceptualizing the process. Community College Journal of Research and Practice October/November 29 (9 \& 10): 689-704.

Anonymous. 2001/2002. New staff development standards issued. Reading Today December 2001/January 200219 (3): 17-18.

Azzam, A. M. 2005. The unprepared administrator. Educational Leadership 62 (8):88-89.

Bernauer, J. 2002. Five keys to unlock continuous improvement. Kappa Delta Pi Record Winter 38 (2): 89-92.

Berry, M. A. R. 2004. Succession to school leadership: Challenge and response for principals. Record of study, Doctor of Education. Office of Graduate Studies of Texas A\&M University. Available at: http://txspace.tamu.edu/bitstream/1969.1/418/1etd-tamu2004A-EDAD-Berry-1.pdf. Accessed on 4 July 2006.

Brundette, M. 2000. The question of competence: The origins, strengths and inadequacies of a leadership training paradigm. School Leadership \& Management August 20 (3): 353-369. Available at: http://www.ce.manchester.ac.uk/downloads/stories_from_a small_school.pdf. Accessed on 4 July 2006.

Bush, T. 1998. The national professional qualification for headship: The key to effective school leadership. School Leadership \& Management August 18 (3): 321-333.

Crow, G. M. 2003. School leader preparation: A short review of the knowledge base. Available at: http://www.ncsl.org.uk/media/93C/03/school-leader-preparation.pdf. Accessed on 4 August 2006.

Council for Higher Education. 2001. Quality Assurance in Higher Education. Available at: http://www.che.ac.za/documents/d000002/index.php. Accessed on 4 August 2006. 
2005a. Council on Higher Education 2005. Higher Education Quality Committee. National review of the structured Master of Education Programmes. Pretoria.

- 2005b: Council on Higher Education 2005. Higher Education Quality Committee. National review of the structured Master of Education Programmes. Pretoria.

Daresh, J. C., M. W. Gantner, K. Dunlap and M. Hvizdak. 2000. Word from 'The trenches': Principals' perspectives on effective school leadership characteristics. Journal of School Leadership January 10 (1): 69-83.

Dreher, E. D. 2002. Leading the Tao: the energizing power of respect. The Learning Organization, 9 (5): 206-213.

Fennell, H-A. 2005. Living leadership in an era of change. International Journal of Leadership in Education April/June 8 (2): 145-165.

Fusarelli, L. D. and L. Smith. 1999. Improving urban schools VIA leadership: Preparing administrators for the millennium. Journal of School Leadership November 9 (6): 534-551.

Gonzales, M., N. Glasman and L. D. Glasman. 2002. Daring to link principal preparation programmes to student achievement. Leadership and Policy in Schools September 1 (3): $265-283$.

Grogan, M. and A. Andrews. 2002. Defining preparation and professional development for the future. Educational Administration Quarterly 38 (2): 233-256.

Glatter, R. 2006. Leadership and organization in education: time for a re-orientation? School Leadership and Management 26 (1): 69-83.

Hale, E. L. and H. N. Moorman. 2003. Preparing school principals: A national perspective on policy and programme innovations. Available at: http://www.iel.org/pubs/ PreparingSchoolPrincipals.html. Accessed on 5 July 2006.

Hallinger, P. 2005. Scholarship in school leadership preparation: The unaccepted challenge. Available at: http://www.ucea.org/JRLE/pdf/vol1/issue1/Hallinger.pdf. Accessed on 5 July 2006.

Hammersley-Fletcher, L. and M. Brudrett. 2005. Leaders on leadership: The impressions of primary school head teachers and subject leaders. School Leadership and Management 25 (1): 59-75.

Harris, B. M. 2004. A systems approach to formative evaluation of instructional programmes. International Journal of Leadership in Education January-March 7 (1): 71-81.

Herrington, C. D. and B. K. Wills. 2005. Decertifying the principalship: The politics of administrator preparation in Florida. Educational Policy Jan/Mar 19 (1): 181-200.

Hess, F. M. and A. P. Kelly. 2005. Learning to lead? What gets taught in principal preparation programmes. Available at: http://www.ksg.harvard.edu/pepg/PDF/Papers/Hess_Kelly_ Learning_to_Lead_PEPG05.02.pdf. Accessed on 5 July 2006.

Jabal, E. 2006. Learning from Hong Kong alumni: Lessons for school leadership. International Journal of Leadership in Education 9 (1): 21-44.

Johnson, J. F. and C. L. Uline. 2005. Preparing educational leaders to close achievement gaps. Theory into Practice Winter 44 (1): 45-52.

Kent, P. 2002. The professional development of principals: Innovations and opportunities. Educational Administration Quarterly 38 (2): 213-232.

Lashway L. 2003. Transforming principal preparation. Eric Digest 165- February 2003. Available at: http://www.eric.uoregon.edu/publications/digests/digest165.html.Accessed on 4 July 2006. 
Lauder, A, 2000. The new look in principal preparation programs. NASSP Bulletin September 84 (617): 23-28.

Lease, A. J. 2002. New administrators need more than good grades. School Administrator June 59 (6): 40-41.

Leithwood, K. A. and C. Riehl. 2003. What we know about successful school leadership. National College for School Leadership. Available at: http://wwwcepa.gse.rutgers.edu/ What $\% 20 \%$ We\%Know\%20_long_\%202003. Accessed on 4 August 2006.

Levine, A. 2005. Educating school leaders. The Education Schools Project. Available at: www.edschools.org/pdf/Final313.pdf. Accessed on 3 July 2006.

Lin, J. 2005. Perception of principals in the southern, urban U.S. and eastern, urban China regarding the selection, preparation, and professional development of elementary principals. Available at: https:/txspace.tamu.edu/bitstream/1969.1/2563/1/etd-tamu2005B-EDAD-Lin.pdf. Accessed on 5 July 2006.

McClay, M. and M. Brown. 2003. Using concept mapping to evaluate the training of primary school leaders. International Journal of Leadership in Education January-March 6 (1): 73-87.

McKerrow, K., R. Dunn and J. Killian. 2003. Beyond the turf wars: collaboration in preparing school leaders. Education Leadership Review Winter 4 (1): 1-10.

Mester, C., D. Visser, G. Roodt and R. Kellerman. 2002. Leadership style and its relation to employee attitudes and behaviour. Industrial Psychology 29 (2): 72-82.

Mestry, R. and B. R. Grobler. 2004. The training and development of principals to manage schools effectively using the competence approach. ISEA 32 (3): 2-19.

Menter, I., C. Holligan and V. Mthenjwa. 2005. Reaching the parts that need to be reached? The impact of the Scottish Qualification for Headship. School Leadership and Management 25 (1): 7-23.

Parker, S. A. and V. P. Day. 1997. Promoting inclusion through instructional leadership: The roles of the secondary school principal. NASSP Bulletin March 1997:83-89.

Quinn, T. 2002. Redefining leadership in the standards era. Principal September 82 (1): $16-20$.

Reeves, J., E. Turner, B. Morris and C. Forde. 1998. Developing a model of practice: Designing a framework for the professional development of school leaders and managers. School Leadership \& Management May 18 (2): 185-196.

Robinson, R. and S. Carrington. 2002. Professional development for inclusive schooling. International Journal of Educational Management 16 (5): 239-247.

Slater, C. L., M. W. McGhee, R. L. Cap, I. Alvarez, C. Topete and E. Iturbe. 2003. A comparison of the views of educational administration students in the USA and Mexico. International Journal of Leadership in Education 6 (1): 35-55.

Somers, J. and E. Sikorova. 2002. The effectiveness of in-service education on teachers' course for influencing teachers' practice. Journal of In-Service Education 28 (1): 95-114.

Sparks, D. 2003. Skill building. Journal of Staff Development 24 (1): 29.

Southworth, G. and H. du Quesnay. 2005. School leadership and system leadership: Essays. The Educational Forum Winter 69 (2): 212-220.

Terry, P. M. 1999. Essential skills for principals. Thrust for Educational Leadership September/October 29 (1): 28-32.

Vick, R. C. 2004. The use of SREB Leadership development framework in preservice preparation programs: A qualitative study. Dissertation. Department of Educational Leadership and 
Policy Analysis, East Tennessee State University. Available at: http://etd-submit.etsu.edu/ etd/theses/ available/etd-0809104-151312/unrestricted/VickR081904f.pdf.

Wilmore, E. 2000. The changing role of school leadership preparation. International Journal of Educational Reform October 9 (4): 349-360.

Wong, P. 2004. The professional development of school principals: insights from evaluation a programme in Hong Kong. School Leadership \& Management May 24 (2): 139-162.

Yu, H., K. Leithwood and D. Jantzi. 2000. The effects of transformational leadership on teachers' commitment to change in Hong Kong. Journal of Educational Administration 40 (4): 368-389. 